\title{
Die kerk se verantwoordelikheid teenoor die onder- wys: Is Artikel $X$ van die Kerkwet (1986) van die Nederduitsch Hervormde Kerk van Afrika teologies verantwoordbaar?
}

\author{
H J Botes \\ Nederduitsch Hervormde Geemente Naboomspruit \\ Tydelik-deeltydse dosent: Departement Kerkgeskiedenis \\ en Kerkreg (Afd A) \\ Universiteit van Pretoria
}

\begin{abstract}
The church's responsibility towards the school: Is Article $X$ of the Church Order (1986) of the Nederduitsch Hervormde Kerk van Afrika theologically well founded?

This article aims to deal with the selfunderstanding of the Nederduitsch Hervormde Kerk van Afrika. In particular, attention is given on church polity and its effect on the practical implementation of the church's task to society and specifically towards education. The article also reflects on the role of children in the church, as well as the commitment to the principle of theocracy.
\end{abstract}

\section{INLEIDING}

Die corsprong van die onderhawige vraag na die teologiese regverdiging van Artikel $\mathrm{X}$ van die Kerkwet (1986) van die Nederduitsch Hervormde Kerk van Afrika is terug te voer na die Hermeneutiese Studiegroepvergadering van die Fakulteit Teologie (Afd A) aan die Universiteit van Pretoria wat op 4 Oktober 1995 plaasgevind het. Genoemde vergadering het gehandel oor die tema Kerk en kultuur.

As gevra word na die regverdiging van Artikel $X$ van die Kerkwet binne kader van 'n gesprek wat handel oor kerk en kultuur, sal die volgende in berekening gebring moet word: Die locus van Artikel $\mathrm{X}$ van die Kerkwet; die doel van die onderhawige artikel; die historiese wortels van genoemde gegewe; die relasie kerk/kultuur (onderwys) en die teologiese begronding van dit alles.

Om uitvoering van bogenoemde onderneming te gee sal uiteraard hoofsaaklik rekening gehou moet word met tekste. Kristeva konstateer dat ons kultuur ( $\mathrm{d}$ i die Westerse kultuur) 'n 'kultuur van tekste' is (Broekman 1993:128), 'n feit wat baie keer nie onder oë gesien word nie. Een.van Kristeva se vooronderstellings is dat nie die wat nie, maar 
die dat van geskrewe werke sentraal staan. Taal en teks is nie maar blote instrumento. nie; dit is oneindig meer. Dieselfde geld vir wetenskapbeoefening, ook vir die natuurwetenskappe. Elke wetenskap konstrueer en is as sodanig 'n produksie van betekenisse binne kader van ' $n$ kultuur wat voordurend gekontinueer word. Daarby representeer die wetenskap; stel aanwesig wat reeds is. Elke teks wat verwek word, gryp terug na tekste wat reeds bestaan.

As antwoord op die relatief eenvoudige vraag gegee moet word of 'n artikel wat handel oor onderwys in die kerkwet/orde tuishoort; moet die vraesteller hoor wat die verband en perspektief van sodanige teks binne konteks is. Ter wille van die aangekondigde onderwerp, sal die verbandhoudende diskoers uiteraard rekening moet hou met bestaande tekste van die Nederduitsch Hevormde Kerk waarin die wese en roeping van die kerk geartikuleer en in die besonder die kerk se gerigtheid op die onderwys geïmpliseer word.

\section{DIE KERKWET VAN DIE NEDERDUITSCH HERVORMDE KERK - ENKELE OPMERKINGS}

Soos reeds aangedui, is die Kerkwet van die Nederduitsch Hervormde Kerk die primêre bron vir die beredenering van die aangekondigde vraagstelling. Daarom pas dit om enkele houtskoolstrepe in verband met die betekenis van 'n Kerkwet te trek. Ten diepste kan geen kerk sonder 'n orde (Kerkwet) klaarkom nie. Trouens, dit is noodsaaklik om '... een goede gang van zaken in het kerklijke leven te verzekern en te bevorder' (Bronkhorst 1959:229). Coertzen (1991:1) formuleer dit soos volg:

Die bestaan van ' $n$ orde of ' $n$ bepaalde reg in die kerk kan beswaarlik ontken word. Enige persoon, of hy nou lidmaat van die kerk is of nie, wat te doen kry met die kerk, kom onontwykbaar in 'n mindere of meerdere mate met die orde of organisasie van die kerk in aanraking.

Wat die Kerkwet van die Nederduitsch Hervormde Kerk van 1986 betref, val dit dadelik op dat die dokument uit twee hoofdele bestaan, naamlik 25 artikels en 204 bepalings. Die 25 artikels van die wet trek die basiese beginsels van die kerklike orde, terwyl die bepalings die toepassing van die basiese grondlyne in die praktyk is (Van Wyk 1989:235).

Hierdie bepalings het volgens (Pont 1982:33) dieselfde regskrag as 'n gewone besluit van die Algemene Kerkvergadering. Die artikels van die wet geniet 'n bepaalde voorrang aangesien die artikels verskans is. Volgens artikel XXV (Kerkwet 1986:9) kan 'n artikel slegs gewysig word met 'n twee-derde meerderheid tydens 'n Algemene 
Kerkvergadering, terwyl ' $n$ bepaling met 'n meerderheid van stem gewysig kan word. Die 25 artikels van die Kerkwet gee 'n heldere omlyning van die kerkbegrip van die Nederduitsch Hervormde Kerk van Afrika.

\section{DIE LOCUS VAN ARTIKEL X BINNE KADER VAN DIE KERKWET (1986) VAN DIE KERKWET VAN DIE NEDERDUITSCH HERVORMDE KERK VAN AFRIKA}

Volgens die 25 artikels spreek dit as 't ware vanself dat die Nederduitsch Hervormde Kerk se selfverstaan hoegenaamd nie dié is van 'n vrywillige organisasie of vereniging nie. Ooreenkomstig die kerk se belydenis is die NHKA se selfwaardering dié van om openbaring te wees van die een heilige algemene Christelike Kerk (Van Wyk 1989: 236). Aldus artikel II, is die genadeverbond die reële en empiriese grondslag van die kerk.

Rautenbach (1978b:15), merk op dat so onlangs as die laat sewentigerjare is van Gereformeerde Kerke kant die onderwysorde in die Hervormde Kerkorde bygehaal as beweerde voorbeeld van die uitwerking van 'n verkeerde kerkbegrip. Soos reeds hierbo aangetoon is, redeneer Rautenbach (1978b:15) ook dat vir die geskikte weerwoord op die bewering dat die Nederduitsch Hervormde Kerk bedien word van 'n verkeerde kerkbegrip: '... moet mens terug na die naaste bron, die Kerkwet self om te bepaal wat presies daarin verorden word vir die lewe en diens van die kerk, want daaruit kan afgelees word wat die eintlike kerkbegrip is. Besinning oor die kerk se instellings werp lig op die kerk as instelling'.

In artikel IV van die Kerkwet word dit duidelik gestel dat die NHKA van die aanname uitgaan dat die kerk se opdrag van Christus ontvang word en as sodanig word Hy as die enigste Hoof bely. Die opdrag wat van Christus ontvang is, sluit onder andere, aldus die Nederduitsch Hervormde Kerk, in om ' ... teenoor owerheid en volk te getuig, en om mede-verantwoordelik te wees vir die Christelike opvoeding van die kinders van kerk en volk' (Artikel IV [f]).

Dit word deur Rautenbach (1978b:15) sterk beklemtoon dat die Nederduitsch Hervormde Kerkwet getuig van 'al sy geledere se betrokkenheid' tot medeverantwoordelikheid in Christelik-nasionale gees in die skole vir die jeug van die hele volk. Rautenbach (1978b:15) verwys ter stawing van pasgenoemde stelling na Artikel $X$ in samehang met IV, VII, IX en XI asook bepalings 2,1 , a; $5 \mathrm{~g}$ en i; 8, 43, 57 en 58 . Dit is die Nederduitsch Hervormde Kerk se 'onderwysorde'. Rautenbach (1978b:15) se betoog ten behoewe van die Nederduitsch Hervormde Kerk is dat 'al sy geledere se betrokkenheid tot medeverantwoordeliheid by die onderwys' ten doel het om juis die aanname van 'n verkeerde Hervormde kerkbegrip te bewys. Ten grondslag van so 'n aanname is die oortuiging dat die Nederduitsch Hervormde Kerk die roeping van die plaaslike gemeentes onderwaardeer waardeur ook die gesag van die ampte in gedrang kom. 
Die Nederduitsch Hervormde Kerk se onderwysorde, soos vasgelê in die Kerkwet (1986) moet egter nie sondermeer as 'n dekreet van 'n kerklike hiërargiese sisteem gesien word nie. Wanneer die NHKA in die Kerkwet uitsprake maak oor die kerk se betrokkenheid by opvoedende onderwys, beteken dit enersyds dat die vergadering van die besondere ampsbekleërs, in diens van die Christus-heerskappy, van Godsweë 'n opdrag het tot bemoeiing met die gemelde aspek (gees) van die openbare onderwys (Artikel IV j, VI, VIII, X, XXV en bepaling 43). Andersyds (en dit word soms moedswillig [?] misgekyk) heet dit 'ter vervulling van die roeping van die priesterskap van die gelowiges'. Hierdeur word al die lidmate van die NHKA opgeroep om die ampsdraers by te staan in die diens van die kerk en naas hulle werksaam te wees in onder andere die apostolaat wat ook die geestelike vorming van die jeug insluit (vgl die Artikel van die Kerkwet [1986] wat handel oor die bedieninge).

Daardie betrokkenheid in aspekte van die burgerlike onderwys is deel van die kerk se opdrag van Godsweë 'tot bewaring en voortdurende hervorming van die Christelike lewensorde in staat en maatskappy' (Bepaling 43). Laasgenoemde betuiging van God se heilsbeloftes en gebooie (die evangelie) voor mense, word as 'die apostolaat van die kerk' aangedui (Rautenbach 1978b:15). Dit wil dat in die openbare onderwyswêreld dié getuienis daartoe moet dien dat ook in daardie lewensverband God se gebooie gestalte mag kry.

Vir doeltreffende behartiging van daardie opdrag deur lidmate, gemeentes, ampsdraers en alle amptelike vergaderings word die NHKA begelei en voorgelig deur ' $n$ 'orgaan van bystand' (Artikel VII), naamlik 'n Raad vir Opvoeding en Onderwys (bepalings 57 en 58) as bevoegde werkgroep met omskrewe opdrag en verantwoording in die kerk. 'Kragtens die leer-, regeer- en tugopdrag wat die ampsdraers in opdrag van Christus uitoefen, is hulle, wanneer gekonstitueer in 'n Algemene Kerkvergadering, bevoeg om wette en bepalings te maak vir die orde en regering van die kerk' (Artikel XXV). Die amptelike vergadering het die NHKA se oortuiging in Artikel X (geestelike vorming van die jeug) en Bepalings 57 en 58 (Raad vir Opvoeding en Onderwys [in verband met sake van kerk en skool] in aansluiting by Artikel VII [organe van bystand]), laasgenoemde met omskrewe opdrag, neerslag laat vind. Rautenbach (1978b: 15) verwoord dit alles so:

Kerkbetrokkenheid en kerkwyse op die bepaalde arbeidsveld van die gees van die openbare opvoedende onderwys, spruit uit die kerkbegrip wat bely word met implikasie vir kerkinrigting, -regering en -werk. Daardie kerkbeeld vind neerslag in die Kerkwet (wette en bepalings) of 
kerkorde; word weerkaats in die kerk se openbare getuienisse oor die onderwys voor owerheid en volk (Artikel II, i en bepaling 43); verder die beleidstukke deur die Algemene Kerkvergadering 1961 en 1973).

Vir verdere toeligting, gesien in die lig van die stelling dat die Nederduitsch Hervormde Kerk se onderwysorde spruit uit 'n verkeerde kerkbegrip (redes vir sodanige uitspraak reeds hierbo genoem), word die volgende logiese afleidings na aanleiding van die Kerkwet (1986) saaklik gestel.

In Artikels I, II en III van die Kerkwet van Nederduitsch Hervormde Kerk van Afrika, herbevestig die NHKA dat dit duidelik prinsipieel kies vir die plaaslike gemeente as basis vir kerkinrigting, werk, kerkorganisasie en opbou. In Artikel I word gesê dat 'Die Nederduitsch Hervormde Kerk van Afrika bestaan uit $a l$ die Nederduitsch Hervormde gemeentes van Afrika'. Artikel II getuig dat 'almal wat tot die kerk behoort, in gemeentes van die kerk wat die plaaslike en normale verskyning van die kerk is, byeengebring word'. In Artikel III word die lidmaatskap van die plaaslike gemeentes uiteengesit.

So gesien, is dit duidelik dat die plaaslike gemeente, saamgestel uit die lidmate daarvan, ' $n$ sentrale funksie in die kerk vervul. Gemeentevergaderings kies kerkraadslede. Laasgenoemdes kom in vergaderings byeen met die oog op die regering van die kerk, wat eintlik 'n Christusvergadering is, omdat die kerk in Artikel XI bely dat 'Christus Hoof van die kerk en Heer van die wêreld' is. Sonder om nou nog 'n graad dieper te daal, kan volstaan word dat wat tot dusver betoog is, duidelik maak dat die regering van die Nederduitsch Hervormde Kerk onder die hoofskap van Christus par excellence ' $n$ sinodaal-presbiterale stelsel is.

Wat van wesenlike belangrik is vir die doel van hierdie diskoers aan die hand van die Kerkwet (1986) van die Nederduitsch Hervormde Kerk as teks, en laasgenoemde as presisering van die kerk se betrokkenheid by opvoedende onderwys, is om te fokus op die reedsgenoemde apostolaat van die kerk. Van Deventer (1985:85) redeneer met dieselfde oortuiging as Rautenbach (1978b:24) dat Artikels IX en X saamgelees moet word om die Nederduitsch Hervormde Kerk se apostolêre verantwoordlikheid jeens opvoedende onderwys te begryp. Artikel IX lui soos volg:

1. In die verwagting van die koninkryk van God, met die volmag van Jesus Christus die Here aan wie alle mag in hemel en aarde behoort, en in gehoorsaamheid aan sy bevel: 'gaan dan na al die nasies toe an maak die mense my dissipels: doop hulle in die Naam van die Vader en die Seun en die Heilige Gees, en leer hulle om alles te onderhou wat ek julle beveel het' (Matt 28:19, 20), vervul die Kerk sy apostoliese opdrag deur: 

a) Bybelverspreiding;
b) Sending onder alle volke;
c) Arbeid onder die Moslems;
d) Die getuienis teenoor die Jode;
e) Die arbeid onder diegene wat van die evangelie vervreem is;
f) Die voortdurende evangelisering en hervorming van die volkslewe.

2. Die kerk rig hom in die sending tot bevolkingsgroepe op gemeenskappe in Afrika wat nog heidens of gedeeltelik heidens is, om hulle te help met die verspreiding van die evangelie in hulle eie gemeenskappe en kerkstening van hulle gemeenskapslewe en deur diegene wat deur daardie diens tot geloof gekom het, by te staan by die inrigting en opbou van 'n eie kerklike lewe sodat hulle uiteindelik tot afsonderlike kerk(e) kom.

3. Die kerk getuig teenoor die Jode dat God wat Hom aan Israel geopenbaar het die Vader van Jesus Christus is, en dat Jesus Christus die Verlosser is in wie al die belofies van God bevestig is (2 Kor 1:20).

4. Die kerk roep diegene wat van die evangelie vervreem is, tot bekering en betuig teenoor owerheid en volk die heerskappy van God op elke terrein van die samelewing en eis dat die samelewing ingerig word volgens die beloftes en wil van God.

(Kerkwet 1986:3 en 4)

Die aangehaalde artikel toon duidelik dat die NHKA die apostolêre roeping van die kerk in die Bybel wil fundeer. Dit dui op 'n poging en feit dat kerk vir alles wat die kerk wil doen, behoorlik rekenskap wil gee van die Bybelse gefundeerdheid van die kerk se handelinge, sodat die werk van die kerk gestalte kan vind in 'n kerkorde wat as 'n presbiteraal-sinodale stelsel die feit verdiskonteer dat Jesus Christus die enigste Hoof van die kerk is.

Nou is dit so dat Christus wat as Hoof van die kerk bely word, die opdrag gegee het dat die heilsboodskap aan die hele mensdom verkondig moet word. Hierdie werk vind plaas vanuit die struktuur van die kerk as liggaam van Christus. Genoemde struktuur is hierbo enigsins breedvoerig bespreek en gefundeer. Dit moet beklemtoon word dat hierdie arbeid van die kerk, voortsetting van die ampswerk van Christus, plaasvind in opdrag van die Heer van die kerk en in verwagting van die koms van die koninkryk 
van die hemel (Van Wyk 1989:327). Om aan Van Deventer (cum Rautenbach) se argument dat Artikels IX en X saamgelees moet word, volle gewig te gee moet vervolgens op Artikel X gelet word. Hierdie Artikel lui soos volg:

Dit is die taak van die kerk om mee te werk aan die geestelike vorming van die jeug, wat sy plek in die gemeente en sy weg in die wêreld moet vind.

Kragtens sy roeping om lewens volgens die beloftes en die wil van God in te rig, is die kerk medeverantwoordelik vir die opvoeding van en die onderwys aan die jeug van die hele volk in 'n Christelike nasionale gees, in huisgesin en skool.

(Kerkwet 1986:4)

Wanneer Artikel IX en X saamgelees word en Artikel XI daarby in berekening gebring word, staan dit buite kyf dat die Hoofskap van Christus deur genoemde artikel bevestig word. Hienuit vloei as ' $t$ ware vanselfsprekend die feit voort, dat die kerk se betrokkenheid by die onderwys as onderdeel van die 'geestelike vorming van die jeug', 'n onontwykbare kerkopdrag is, 'n opdrag in gehoorsaamheid aan die Hoof van die kerk. Artikel X bied verder ook 'n besondere gerigtheid aan die kerk se apostolêre bedrywighede. 'n Gerigtheid op die kind se uiteindelike plek in die gemeente en as sodanig op die kind se weg deur die wereld (Van Deventer 1987:88).

Bostaande Artikel sonder die opvoedende onderwys uit as 'n lewensvorm wat gekersten moet word. In 'n referaat wat Van Ruler (1954:17) in 1954 voor 'n afdeling van die Nederlandse Hervormde Kerk se Raad insake Kerk en Skool gehou het oor 'De kerstening van het voorbereidende Hoger en Middelbaar Onderwys, in verband met apostolaat', verklaar hy:

Wij zien onszelf en elkaar tegenwoordig op een zeerbewuste en opzettelijke wijze bezig in de arbeid van de kerstening van de onderscheiden gebieden van het leven. Dat ligt zonder twijfel aan ... en aan het steeds sterker gaan zien van de taak welke de kerk van Godswege heeft in en voor de wereld. Wij noemen dat het apostolaat van de Kerk.

Die apostolêre taak en roeping van die kerk moet uiteraard ook die opvoeding en georganiseerde onderwys insluit. Van Deventer (1987:87) pleit dat: 
Die owerhede moet toesien dat die middele en strukture geskep word en voorsien word terwyl die kerk deur sy getuienis en bemoeienis voortdurend proklameer dat elke vorm van bouwerk in die volkslewe met inbegrip van die onderwys slegs kan geskied op die een fondament waarvan 1 Kor 3:11 getuig ...

Hoewel hierdie praktiese werkwyse seker nie meer heeltemal moontlik is in 'n getransformeerde Suid-Afrika nie, kan die kerk seker nooit ophou om as Christus-belydende geloofsgemeenskap in die wêreld volhardend te bly getuig van Christus se beloftes nie. By alles bied Artikel $X$ 'n besondere gerigtheid aan die kerk se bedrywigheid in die wêreld.

\section{DIE NEDERDUITSCH HERVORMDE KERK IS VERBIND TOT DIE TEO- KRATIESE BEGINSEL.}

Wat tot dusver betoog is in verband met apostolaat, die kerk-wêreld visie en die Hoofskap-Heerskap van Christus oor kerk en wêreld, gee uitdrukking aan wat as die teokratiese siening bekend is. Van Ruler, bekendste woordvoerder van hierdie eeu oor teokrasie, het geskrywe:

Historisch heeft het wezen van de theocratie daarin gelegen dat de Kerk de overheid steeds kritisch en profetisch er aan heeft herinner, dat ook zij niet lukraak haar gang kan gaan, omdat zij onder de geboden Gods staat en zich aan dezen heeft te onderwerpen.

(Van Ruler, in Rautenbach 1978b:22)

Prof Otto de Jong (1978:400) het in 1972 as eminente Nederlandse kerkhistorikus geskrywe: 'De ontwerpkerkorde (d i die Nederlandse Hervormde Kerk Kerkorde van Desember 1950) ging vooral de stempel dragen van A A van Ruler'. Ook 'n ander invloedryke Hollandse historikus, te wete A J Rasker (1974:312), het De Jong in sy standaard geskiedskrywing van die Nederlandse Hervormde Kerk hierin gelyk gegee. De Jong (1978:401) het met 'n terugblik verklaar:

In dat Ou Testament zag hij [Van Ruler] de grondlijden voor het politieke bestaan van de mens in de wereld en zag hij het als roeping van de Christen om de wereld in te richten, want de wereld is de eigenlijke terrein waar de naam Gods wil wonen. Deze theocratische visie legde Van Ruler in de Kerkorde. 
Wat van belang is om te stel, is dat genoemde Nederlandse Hervormde Kerkorde van 1950 die volkome agtergrond vorm van die Nederduitsch Hervormde Kerk se kerkwet wat tans nog geldig is. (Rautenbach 1978:a22). So onlangs as 1986 het die NHKA tydens 'n Algemene Kerkvergadering na aanleiding van 'n referaat van prof J P Oberholzer eksplisiet gekies vir die onderskrywing van die teokratiese beginsel:

Daarom betuig en bely hy [die kerk]. Hy [die kerk] proklameer die teokrasie nie as 'n sisteem naas of ter vervanging van ander sisteme nie, maar as ' $n$ waarheid wat hy uit die openbaring van God ken, die openbaring in en deur Jesus Christus wat die heerskappy van God laat ken as skeppende, voorsienende, reddende, straffende teenwoordigheid.

(Oberholzer 1985:14)

Die instemming van die Algemene Kerkvergadering van 1986 met Oberholzer se referaat, beteken dat die kerk die gesag van God, as enigste gesag in die ganse wêreld ag waaraan die kerk primêr gehoorsaam is. Alle gesag van owerhede is verleende gesag van God. In die onderhawige studiestuk, wat die kerk aanvaar het, getuig die kerk vanuit ' $n$ teokratiese visie teenoor die owerheid ook oor die onderwys. Dit is 'n selfrefleksie van die NHKA oor hoe die kerk betrokke en verantwoordelik ten opsigte van hierdie aangeleentheid wil wees.

Naas die getuienis teenoor die owerheid oor opvoeding, onderrig en kultuur, waarin die kerk kom met 'n eis dat die samelewing ingerig word volgens die beloftes en die wil van God juis op die vlak waar dit blywende effek kan hê, staan die kerk wag oor die nougesette aandag aan kind en jeug. Die tradisie van die kerklike inset op hierdie gebied is van ouds gevestig. Die Nederduitsch Hervormde Kerk het in sy keuse vir staatskole waarin die opvoeding en onderrig in Christelik-nasionale gees geskied, gekies vir medeverantwoordelikheid met die owerheid en so uiting gegee aan sy ywer vir 'n Christelike lewensorde in staat en maatskappy. Dit berus op 'n wedersydse welwillenheid en kon alleen realiseer omdat die gesagsdraers in die owerheid in geloof en volksverband een was met die lede van die kerk. Die vloeibare owerheids- en staatstruktuur sowel as die veranderde onderwysbedeling sal mettertyd moontlik nuwe situasies skep, maar sal die medeverantwoordelikheid van die kerk nie verminder nie. Naas die direkte betrokkenheid by sake van 
skool en universiteit, sal die kerk voortgaan om saam met ander samelewingsverbande en afsonderlik hom in te set vir die onderwys en opvoeding in Christelik-nasionale gees en vir die vorming van die jeug op 'n wyse wat die eer van God en die heil van die samelewing sal dien.

(Oberholzer 1985:20)

\section{VOLKSKERKLIKE OORWEGINGE MET BETREKKING TOT OPVOED- ENDE ONDERWYS}

In die bespreking van die apostolaatsartikel (IX) hierbo, is herhaaldelik gestel dat genoemde artikel na betrokkenheid in die volkslewe of nasionale gemeenskap as kerkopdrag (van Godsweë) verwys. Bewaring en uitbouing van 'n Christelike lewensorde deur staat en volk impliseer ook vestiging en bevordering van 'n Christelike skoolorde in die geestelike vorming van die jeug van die hele volk 'na die eis van die Woord van God' of 'in 'n Christelik nasionale gees'. Rautenbach (1978a:23), noem dit 'behartiging van 'n volkskerklike funksie of roeping'.

Die woord 'volk' verskyn ses keer in die sentrale apostolaats Artikel (IX). Die bevordering van die ryk van God word twee maal regstreeks en eenmaal by implikasie genoem. Dit alles benadruk ' $n$ besondere teokratiese kerk-wêreld siening. Die NHKA het ' $n$ roeping jeens die volk waaronder die kerk leef en verkondig.

Inmiddels moet gestel word, dat wanneer oor die NHKA se volkskerklike funksie en roeping, ook jeens opvoedende onderwys, gehandel word, dit die diskoers dwing om oor die Nederduitsch Hervormde Kerk as volkskerk te besin. Nou is dit so dat die binne-kerklike debat oor die volkskerkbegrip beslis nog nie afgehandel is in die Nederduitsch Hervormde Kerk nie. Nuwe perspektiewe oor die 'kontroversiële onderwerp' word steeds geopen. In die verband kan ondermeer verwys word na Ernest Van Eck se onlangse bydraes in die Hervormde Teologiese Studies (vgl Van Eck 1995a:825-850; 1995b:1114-1126).

In elk geval, om die oog vir 'n oomblik weer te vestig op die primêre teks van ondersoek in hierdie diskoers, moet gewys word op die feit dat die woord 'volkskerk' net eenmaal voorkom in die artikels van die 1986-Kerkwet van die Nederduitsch Hervormde. Dit staan dan in verband met die NHKA se sendingarbeid wat gerig is op die vorming van volkskerke of kerke in volksverband, soos die saak onder andere beslag gekry het in Julie 1977 tydens die eerste Algemene Kerkvergadering of (Sinode) van die selfstandige sendingkerk, die Hervormde Kerk in Suidelike Afrika. Ook in die sending-subartikel van die Nederlandse Hervormde Kerkorde van 1950 (wat die basis vorm van die Nederduitsch Hervormde Kerk van Afrika se Kerkwet) word die volgen- 
de verneem 'De Kerk dient deze gemeenten by de inrichting en opbouw van een eigen kerketyk leven'. Rautenbach (1978a:23) stel kategories dat daarin die stem van prof H Kraemer (1888-1965) duidelik opklink. Kraemer was 'n sendingkundige en kenner van Islam, maar ook lid van die Kommissie van die Ontwerp Kerkorde van die Nederlandse Hervormde Kerkorde van Desember 1950. Kraemer was bekend daarvoor dat hy sterk gekant was teen alle kerklike kolonialisme en het strykdeur aangedring op agting in die nasionale strewe van die volke van Indonesië waarby Nederland vir ' $n$ tydlank betrokke was.

Dit wat Van Eck (1995a:872) oopdek, naamlik dat Artikel 11 (wat oor lidmaatskap en sendingbeleid handel) van ... 'die Hervormde Kerk 'n eksklusiewe volkskerk', maak verdien oorweging. Aan die ander kant vra die gedagte van Van Zyl (1987:7) ook nadenke. Volgens Van Zyl beoog 'n volkskerk niks meer nie as om 'n volk in wie se midde die kerk kerk is, met die evangelie van Christus te dien, onder die kruisbanier van Christus te bring. ' $n$ Volkskerk is dus niks anders as die volk van God in 'n volk nie. Hierby sluit Van der Westhuizen (1987:15) aan as hy klem lê op die feit dat die volkskerk na die gerigtheid van die kerk wys:

Van kop tot tone is volkskerk kerk van die Bybel. Ten volle is dit die liggaam van Christus. Sy oë sien die volk raak, sy ore hoor die volkstaal, sy mond spreek die moedertaal, sy hande handel op die volksterreine, sy voete bewandel die vaderland van sy volk, sy hart ken die vrese en liefdes, die swakheid en roem, die selfsug en lafhartigheid van sy volk. Daarom kan hy die gedagtes uit die brein of die Woord van Sy Hoof met sensitiwiteit (Rom 12:2; Fil 1:9, 10), doelgerigtheid en klaarheid spreek.

J H Koekemoer $(1987: 14,16)$ wys weer op die apostolêre taak van die volkskerk, as hy sê: 'n Volkskerk sal altyd kerk van die Here moet wees wat die evangelie ook aan 'n bepaalde volk moet verkondig. Hy sal in die ganse lewe van die volk kerstenend moet inbeweeg, maar hom nooit so met die volk kan identifiseer dat hy sy kritiese ingesteldheid op die lewe van die volk sal verloor nie'.

Bostaande aanhalings laat die aksent nie primêr val op oop of toe kerke of entnisiteit as sodanig nie, maar op die werklikheid van kerkwees onder ' $n$ bepaalde volk. Dit is ' $n$ uitgangspunt wat aan ander volke verkondig mag word as werkwyse tot kerstening van die wêreld.

Die bedoeling is nie om met hierdie artikel die begrip 'volkskerk' volledig te beredeneer nie. Daar word alleen gepoog om aan te toon dat die NHKA se selfverstaan dié is van kerk van Christus onder die volk wat al die geledinge van die volkslewe moet 
kersten. Dit spreek vanself dat wanneer 'n kerk kerkwees só verstaan, dan kom die onderwys van die volk in die gesigsveld van die kerk se bestaan. Dit beteken dus dat nie net die onderwys van dooplidmate die kerk aangaan nie, maar ook die onderwys van die kinders van die volk. Dit is alles so, omdat 'n Christus-belydende volkskerk algemeen is. Die Reformasie, waarin die Christus-belydende volkskerk ingebed is, het juis in die katolisiteit van die kerk die trek van die nasionale ontdek (Van Ruler 1947: 10).

Die geskiedenis het geleer dat die na-Reformatoriese kerk katoliek geword het toe die kerk die kleur van die omgewing aangeneem en kerk onder die verskillende volke geword het. Die vertaling van die Bybel in die verskillende tale en die gebruik van die inheemse taal in die erediens, sodat elke volk in die eie taal kan hoor: 'só spreek die Here', is die sprekende bewys daarvan. By alles het die Reformasie geleer dat God aanwesig is in voor- en teëspoed, aanwesig onder elke volk en taal en nasie. Dit het aan die Europese lewe in totaal ander wêreldbeeld gebied (Van Ruler 1947:11). Die Hervorming het ook aan die mensdom geleer wat ware vryheid is. Ware vryheid is geleë in die vryheid van die Woord, die openbaring van God. Elke mens kon van toe af die Bybel lees in sy of haar eie taal. Die Bybel, wat oor gesag beskik, is in staat om sigself uit te lê en het onstuitbaar 'n bepaalde loop geneem. So het die waarheid toeganklik geword vir elke mens. So het dit gebeur dat ook die kultuur, of te wel die ganse menslike lewe, gekersten is. Die kerstening het nie geskied via Christelike organisasies of Christelike verenigings nie, maar deur die kerk as volkskerk. Volksgewys is die wêreld volgemaak met die waarheid van Jesus die Heer, so het dit gebeur dat oral waar die Hervorming wortel geskiet het, die kruis van Golgotha in die midde van die kultuur van die Hervormde-gemenebes te staan gekom het. Rondom die middelpunt is die lyne van reg en geregtigheid getrek en is die lewenswêreld georden.

Met dié benadering spreek dit vanself dat die kerk nie belas hoef te word met ' $n$ 'kultuurtaak' nie. Die kerk aanvaar die taal, tradisies en kultuur van die adres waar die evangelie verkondig moet word (Van der Westhuizen 1996:150). Sonder om kultuur doelbewus te bevorder, sonder om sigself 'n kultuurtaak op te lê, sal dié kerke wat hulle primêre roeping binne konteks van die Reformatoriese tradisie nakom, 'n stempel op die kultuur nalaat. Dit is wat die kerstening van die kultuur deur die kerk impliseer.

\section{DIE KIND SE PLEK IN DIE KERK}

In die lig van onderhawige gegewens, is dit van betekenis dat gelet moet word oor hoe die NHKA die plek van die kind in die kerk verstaan. Om dit enigsins te kan begryp, moet ten eerste rekening gehou word met die verbondsmatige karakter van die kerkbegrip van die Nederduitsch Hervormde Kerk. Hierdie verstaan van die wese van die 
kerk word deur Artikel 11 van die Kerkwet en Bepalings (1986) verwoord: 'Ter wille van die goeie orde word almal wat deur die genadeverbond tot die kerk behoort, byeengebring in gemeentes'. Wanneer die verbondsmatige karakter van die kerk, en daarmee saam die lidmaatskap, orweeg word, word die mens as lidmaat van die kerk in 'n ander lig beskou. Dan val die klem nie meer op die mens wat vrywillig tot die kerk toetree op grond van sy of haar belydenis, gerugsteun deur die feit dat die enkeling uitverkies en wedergebore is nie, maar op die genadeverbond, op God wat op grond daarvan die gelowiges ingesluit het in die verbond met Hom (Van Wyk 1989:336).

So gesien, is dit duidelik dat die kerk aan die gelowiges voorafgaan. Van Wyk stel dit nog sterker deur te sê dat mense nie tot die kerk toetree wanneer hulle gedoop word, of soos dit dikwels gestel word, wanneer hulle belydenis van geloof aflê nie, maar mense word binne die kerk gebore: 'Die mens word nie lidmaat van die kerk nie, maar is lidmaat van die kerk. Die verbondsmatige verpligting om aan die kerk te behoort, hef alle menslike voor- en afkeur af' (Van Wyk 1989:336). Wanneer hierdie stelling verder beredeneer word, is dit eintlik vanselfsprekend dat wanneer die klem op die vrywillige toetrede tot die kerk deur die wedergebore val, dit wil sê op die bekeerde mens vanweë sy of haar belydenis, dan kom die vooronderstelling dat die kerk 'n vrye vereniging is, vanself ter sprake. As die mens nie deur middel van die doop as lidmaat van die liggaam van Christus bevestig word nie, dan word die hele verhouding Godmens afhanklik gemaak van die keuse van die mens. Wanneer die lidmaatskap bepaal word deur die mens se keuse, kom die vraag na vore: wat moet met die mens se kinders gedoen word? Want, solank hulle nog nie self welbewus 'n keuse kan uitoefen nie, moet hulle dan noodwendig soos heidene behandel word.

Die NHKA, anders as byvoorbeeld die Nederlandse Hervormde Kerk, bepaal in Artikel 11 van die Kerkwet (1986) uitdruklik dat kinders ook lede van die kerk is. Daarmee word die verbondsmatige karakter van die kerk beklemtoon en die gerigtheid van die kerk as volkskerk onderskryf.

In die lig van wat alles tot dusver betoog is aangaande die verbondsmatige kerkbeskouing en die implikasie van lidmaatskap en die wyse waarop kinders betrokke is, is dit duidelik dat die gelowige huisgesin 'n besondere plek in die kerk inneem. Die gelowige huisgesin is as 't ware ' $n$ huisgemeente wat deel uitmaak van 'n groter geheel (Pont 1989:459; Van Wyk 342) verwoord die organiese werklikheid so:

Behalwe die verband as gelowige lidmaat met die gemeente, staan die lewe van die gelowige ook in nouste verband met die gelowige huisgesin. Want as die kinders van gelowiges gedoop word en in die kerk opgroei, word die verband tussen ouer en kind belangrik, veral in die lig van die doopbelofte wat die ouer aflê, en kom die huisgesin na vore as die huisgemeente. 
Juis deur die doopbelofte wat in die kerk afgelê word, het nie net die ouer 'n opgaaf jeens sy gedoopte kind nie, maar ook die kerk. Die kerk moet immers toesien dat die doopbelofte van die ouer nagekom word. As sodanig is die kerk in geheel, via die lidmate met gedoopte kinders, betrokke by die gebeure waar die dooplidmate in skoolverband opgevoed moet word. Dit is 'n gegewe dat skoolgaande kinders die grootste deel van hulle skoolleeftyd op skool is. Dit beklemtoon die feit dat die kerk 'n besondere roeping het teenoor dooplidmate. Dit alles kom ook daarop neer dat die onderwys een van die belangrikste samelewingsfunksies is in die behoud en uitbouing van 'n gekerstende volkslewe en kultuur. Dis juis om dié rede dat die NHKA die onderwysopdrag. tussen die sentraalste verordeninge in die Kerkwet plaas.

\title{
7. STEMME OOR DIE ONDERWYS UIT DIE DAE VAN DIE REFORMASIE
}

\begin{abstract}
Het kan nauwlijks verbasing wekken dat protestanten, door zich in de lectuur van die bijbel te verdiepen, wel grote belangstelling moesten koesteren voor het onderwijs. Luther en Calvijn, die zich sterk interesseerden voor pedagogische problemen, werden hierin gevolgd daar hun discipelen, maar ook daar hun katholike tegenstanders: sinds die tijd zijn alle Kerken zich bewust van de Kerken macht van de onderwijzer.
\end{abstract}

(Mutzenberg 1990:261)

Een van die erfnisse van die Hervorming was dat predikante in die sestiende eeu dikwels ook naas hulle pastorale verpligtinge onderwysers moes wees. Guillaume Farel (Mützenberg 1990:262) het die onderwys beskou as 'n middel om die kerkhervorming te bevorder.

Na zijn uitwijking uit Geneve in Oktober kom hij op het idee om gebruik te maken van die diensten van een tussenpersoon en zich voor te doen als onderwijzer, teneinde hier de reformatie te propageren. Die jonge predikant van Yvonard, Antonie Froment, word vooruitgestuurd om overal in de stad kleine handgesckreven aanplakbiljetjes op te hangen: 'Er is een man in deze stad gekomen die een ieder dit wenst in een maand tijds lezen en schrijven in het Frans kom leren, jong of oud, man of vrouw, zelfs dezulken die nimmer een school hebben bezocht. En indien zij na de voornoemde maand niet kunnen lezen en sckrijven zal hij voor zijn werk geen betaling vragen ....' De lokkende tekst treft doel. Deze ... 
geven een illustratie van de rol die de school kan spelen in een beweging voor welke de Heilige Schrift centraal staat, in kerk, gezin en individuele pesoonlijkheid.

(Mützenberg 1990:262)

Luther het in 1542 alle magistrate van alle Duitse stede aangemoedig om Christelike skole te stig (Mützenberg 1990:263). Luther het daarop aangedring dat die verantwoordelikheid van die opvoeding van kinders nie uitsluitlik aan die ouers oorgelaat moet word nie, omdat hy gereken het dat die meeste nie daarvoor bevoeg was nie. In 1530 , in 'n preek wat gehandel het oor die verpligting tot onderwys, het Luther gestel dat '... de Heilige Schrift moet een essentieel onderdeel van het onderwijsprograma vorm' (Mützenberg 1990:262). Hy het ook onomwonde gestel dat die Skrif natuurlik nie die enigste onderdeel van die lesprogramme moet uitmaak nie en het daaraan toegevoeg: 'Talen, kunst, geschiedenis, zingen en rekenen morge evenmin ontbreken' (Mützenberg 1990:262). Luther het 'n ruim beskouing oor onderwyssake gehad. Hy het gepleit vir 'n ewewig tussen kultuur, familieverbande en die bestudering van 'n vak. Die allesbelangrikste vir hom, soos blyk in sy manifes van 1520 aan die Christelike adel van die Duitse nasie, was dat die kind in kontak met die evangelie moet kom.

Calvyn wat reeds tydens sy Straatsburgse verblyf hom met onderwysprobleme besig gehou het, het met sy terugkeer na Genève op toegespitse wyse betrokke geraak by die vestiging van skole vir die jeug (Mützenberg 1990:264). Vir Calvyn was godsdiens en onderrig nou verbonde. As sodanig was skool en kerk groothede wat mekaar moet aanvul (Walker 1969:360).

\section{GEVOLGTREKKING}

Die vernaamste teks(te) voorhande waarin die NHKA se onderwysbetrokkenheid verantwoord word, is in behandeling geneem. Kragtens die NHKA se selfverstaan, teokratiese visie en apostolêre opgaaf, blyk dit dat die NHKA 'n onontwykbare taak as kerk het jeens die opvoedende onderwys. Teologie bly egter altyd net mensewerk. Dit beteken dat onderhawige konsepte en beginselbesluite voortdurend oordink en beredeneer sal moet word. Dit wat hierbo in verband met die taak en verantwoordelikheid van kerk jeens onderwys uiteengesit is, dui op die status quo in hierdie verband binne die Nederduitsch Hervormde Kerk van Afrika.

\section{Literatuurverwysings}

Broekman, J M 1993. Julia Kristeva: Eenheid en verscheidenheid van mens en kultuur, in Moderne Franse Filosofen. Kampen: Kok Agora.

Bronkhorst, A J 1959. Kerkorde in Christelijke Encyclopedia, deel 4. Kampen: Kok. 
Coertzen, P 1991. Gepas en ordelik. Pretoria: RGN.

De Jong, Otto J 1974. Nederlandse Kerkgeskiedenis vanaf 1795. Kampen: Kok.

Koekemoer, J H 1987. Die volkskerkvoorstelling in die Kerkwet van die Nederduitsch Hervormde Kerk van Afrika. HTS 43/1 \& 2, 13-24.

Mützenberg, G 1990. Groeiend gezag van de schoolmeester, in Chaumu, P (red), De Reformatie. Abcoude: Uniepers.

Oberholzer, J P 1985. Die taak van die kerk teenoor die owerheid. HTS 41/1, 14-28.

Pont, A D 1982. Kerk en volk. HTS 25/1, 202-218.

1989. Die priesterskap van die gelowiges soos Calvyn dit gesien het. HTS 45/2, 451-460.

Rasker, A J 1974. Die Nederlandse Hervormde Kerk vanaf 1795. Kampen: Kok.

Rautenbach, C H 1978a: Verbande en Perspektiewe: Drie Temas met agtergrond. Die Hervormer, November 19,78, bl 15-24.

1978b. Verbande en perspektiewe: Drie temas met agtergrond. Die Hervormer, Oktober 1978, bl 22-23.

Van Deventer, H T 1987. Die begronding van die Nederduitsch Hervormde Kerk van Afrika se onderwysbeleid 1902-1985. DD-proefskrif, Universiteit van Pretoria.

Van der Westhuizen, H G 1986. Volkskerk as normale kerkbeskouing. Ongepubliseerde memorandum voorgelê aan die Kommissie van die Algemene Kerkvergadering van die Nederduitsch Hervormde Kerk van Afrika.

- 1996. Kerk en staat. Almanak en Bybelse Dagboek 90, 149-153.

Van Eck, E 1995a. Greyvenstein, J H J A \& Geyser, A S se teologiese denke oôr die volkskerkgedagte. HTS 51/3, 825-850.

1995b. Maaltye as seremonies in die Markusevangelie: 'n Sleutel om J H J A Greyvenstein \& A S Geyser se denke oor die Nederduitsch Hervormde Kerk as volkskerk te evalueer. HTS 51/4, 1085-1113.

Van Ruler, A A 1947. Visie en vaart. Amsterdam Holland.

1954. Kerstening van het voorbereidend hoger en middelbaar onderwijs. Nijkerk: Callenbach NV.

Van Wyk, B J 1989. Die presbiteraal-sinodale kerkbegrip met besondere verwysing na die Kerkwet van die Nederduitsch Kerk van Afrika. DD-proefskrif, Universiteit van Pretoria.

Walker, W 1969. John Calvin. New York: Schocken Books. 